\title{
Olaparib-mediated enhancement of 5- fluorouracil cytotoxicity in mismatch repair deficient colorectal cancer cells
}

\author{
Helena de Castro e Gloria', Laura Jesuíno Nogueira², Patrícia Bencke Grudzinski²,
}

Paola Victória da Costa Ghignatti ${ }^{2}$, Temenouga Nikolova Guecheva ${ }^{2}$, Natalia Motta Leguisamo ${ }^{2 \dagger}$ and Jenifer Saffi ${ }^{{ }^{*+}}$

\begin{abstract}
Background: The advances in colorectal cancer (CRC) treatment include the identification of deficiencies in Mismatch Repair (MMR) pathway to predict the benefit of adjuvant 5-fluorouracil (5-FU) and oxaliplatin for stage II CRC and immunotherapy. Defective MMR contributes to chemoresistance in CRC. A growing body of evidence supports the role of Poly-(ADP-ribose) polymerase (PARP) inhibitors, such as Olaparib, in the treatment of different subsets of cancer beyond the tumors with homologous recombination deficiencies. In this work we evaluated the effect of Olaparib on 5-FU cytotoxicity in MMR-deficient and proficient CRC cells and the mechanisms involved.

Methods: Human colon cancer cell lines, proficient (HT29) and deficient (HCT116) in MMR, were treated with 5-FU and Olaparib. Cytotoxicity was assessed by MTT and clonogenic assays, apoptosis induction and cell cycle progression by flow cytometry, DNA damage by comet assay. Adhesion and transwell migration assays were also performed.

Results: Our results showed enhancement of the 5-FU citotoxicity by Olaparib in MMR-deficient HCT116 colon cancer cells. Moreover, the combined treatment with Olaparib and 5-FU induced G2/M arrest, apoptosis and polyploidy in these cells. In MMR proficient HT29 cells, the Olaparib alone reduced clonogenic survival, induced DNA damage accumulation and decreased the adhesion and migration capacities.

Conclusion: Our results suggest benefits of Olaparib inclusion in CRC treatment, as combination with 5-FU for MMR deficient CRC and as monotherapy for MMR proficient CRC. Thus, combined therapy with Olaparib could be a strategy to overcome 5-FU chemotherapeutic resistance in MMR-deficient CRC.
\end{abstract}

Keywords: Colorectal cancer, Mismatch repair, 5-fluorouracil, PARP, Olaparib

\footnotetext{
* Correspondence: jenifers@ufcspa.edu.br

${ }^{\dagger}$ Natalia Motta Leguisamo and Jenifer Saffi share senior authorship.

${ }^{1}$ Laboratory of Genetic Toxicology, Federal University of Health Sciences of

Porto Alegre (UFCSPA), Sarmento Leite st 245, Porto Alegre, RS, Brazil

Full list of author information is available at the end of the article
}

(c) The Author(s). 2021 Open Access This article is licensed under a Creative Commons Attribution 4.0 International License, which permits use, sharing, adaptation, distribution and reproduction in any medium or format, as long as you give appropriate credit to the original author(s) and the source, provide a link to the Creative Commons licence, and indicate if changes were made. The images or other third party material in this article are included in the article's Creative Commons licence, unless indicated otherwise in a credit line to the material. If material is not included in the article's Creative Commons licence and your intended use is not permitted by statutory regulation or exceeds the permitted use, you will need to obtain permission directly from the copyright holder. To view a copy of this licence, visit http://creativecommons.org/licenses/by/4.0/. The Creative Commons Public Domain Dedication waiver (http://creativecommons.org/publicdomain/zero/1.0/) applies to the data made available in this article, unless otherwise stated in a credit line to the data. 


\section{Background}

Colorectal cancer (CRC) is a major health problem worldwide owing to its high prevalence and mortality rates [1]. The standard regimen of CRC consists in 5fluorouracil (5-FU)-based chemotherapy alone or in combination with oxaliplatin and/or irinotecan and targeted-therapies [2]. However, the improvements of these combinations in clinical outcomes are limited, mostly because of drug resistance [3]. Thus, the identification of biological factors to enhance the therapeutic response could improve survival rates in CRC patients.

The substantial progresses in the comprehension of CRC molecular complexity allowed the recent developments in the clinical management of this disease, including the identification of microsatellite instability (MSI) $[4,5]$. MSI in sporadic CRC occurs as a result of random $h M L H 1$ promoter hypermethylation, which leads to the inactivation of mismatch repair (MMR) pathway [6]. MMR deficiency (dMMR) in early stage CRC predicts lower recurrence rates and partially justifies the absence of indication of fluoropyrimidine adjuvant monotherapy $[7,8]$. In counterpart, patients harboring stage III dMMR/MSI tumors benefit from oxaliplatin-based adjuvant chemotherapy $[9,10]$.

The 5-FU-mediated cell death mechanisms include thymidylate synthase (TS) inhibition, dNTP pool imbalances and misincorporation of uracil and fluorouracil bases into DNA during replication. Proficient MMR (pMMR) CRC cells have increased sensitivity to 5 -FU in comparison to dMMR CRC cells. The differences between these two molecular phenotypes occur due to a generation of a futile cycle of repair in the attempt to remove uracil and fluorouracil bases during DNA replication in pMMR CRC cells [11]. Base Excision Repair (BER) pathway also imposes its own toxicity, triggered by uracil-DNA glycosylase (UDG) and AP endonucleases [12-14]. Finally, if 5-FU is not removed from DNA, UDG creates lesions, such as abasic sites, single-strand DNA breaks (SSBs) and doublestranded DNA breaks (DSBs) that activate Homologous Recombination Repair (HRR) [15].

In this scenario, emerges the fundamental role of Poly (ADP-ribose) Polymerase-1 (PARP-1) that senses and binds SSBs, favoring the assemble of DNA repair effectors at the site of damage [16]. Besides its essential role in BER pathway, PARP-1 regulates replication fork progression [17]. Chemical inhibition of PARP1 impairs its catalytic activity, generating and impeding SSBs repair [18]. Persistence of SSBs stall and collapse replication fork resulting in DSBs [19]. HRR-deficient tumors are highly sensitive to PARP inhibitors (PARPis), such as Olaparib (AZD2281) [20-22].

PARP inhibition antineoplastic effects are not limited to HRR-defective tumors, and it is considered a radioand chemosensitizer [23, 24].
It was recently proposed that replication stressassociated DSBs also induce MSI in AMMR cells and MSI tumors exhibit mutations within DNA repair genes [25], which could increase the susceptibility to PARP inhibition [26-29]. Although clinical relevance of MMR status in CRC prognosis and response to 5 -FU is undeniable [30], information regarding efficacy of this agent and PARPis in CRC cells with different genetic backgrounds is still controversial [31-33]. Thus, the aim of this study was to evaluate the effect of the PARPi Olaparib on 5-FU cytotoxicity in MMR-deficient and proficient CRC cells and the mechanisms underpinning this response.

\section{Methods}

\section{Reagents and drugs}

Culture media and supplements (Dulbecco's Modified Eagle's Medium low glucose (DMEM); fetal bovine serum (FBS); penicillin/streptomycin, trypsin/EDTA; antimycotic) and Trypan Blue were all purchased from Gibco (Life Technologies do Brasil Ltda., São Paulo, SP, Brazil). 5-fluorouracil (Cas number 51-21-8), MTT (3(4,5-Dimethylthiazol-2-yl)-2,5-diphenyltetrazolium bromide) (Cas number 298-93-1), propidium iodide (PI; Cat number 25535-16-4) and Dimethyl Sulfoxide (DMSO; Cas number 67685) were all purchased from Sigma-Aldrich (Merck KGaA, Darmstadt, Germany). Olaparib was purchased from Toronto Research Chemicals (Cat number 763113-22-0, Toronto Research Chemicals, North York, ON, Canada). PE Annexin V Apoptosis Detection Kit I was purchased from BD Bioscience (Cat number 559763, BD Bioscience, Franklin Lakes, NJ, USA). All other chemicals and solvents used were of analytical or pharmaceutical grade.

\section{Cell line and culture conditions}

Two representative human colorectal cancer cell lines with different status of MMR proficiency, HCT116 (MSI, $\mathrm{MLH}^{-/-}$and $\mathrm{MSH}^{-/-}, \mathrm{KRAS}^{\text {mut }}, \mathrm{TP}^{\mathrm{wt}}{ }^{w t}$ ) [34] and HT29 (MSS, BRAF $F^{\text {mut }}$ and TP53 ${ }^{\text {mut }}$ ) [35] were originally obtained from ATTC ${ }^{\bullet}$ (Manassas, VA, USA). Cells were cultured in DMEM medium, supplemented with $10 \%$ FBS and $1 \%$ penicillin/streptomycin and antimycotic, incubated at $37{ }^{\circ} \mathrm{C}$ in humidified atmosphere with $5 \% \mathrm{CO}_{2}$. Cultured cell concentrations were adjusted to allow for exponential growth. At $80 \%$ of confluence, cells were detached with $0.5 \%$ of trypsin/EDTA and used for the experiments.

\section{Experiment setup}

Cells were seeded at different densities according to the experiment performed. After $24 \mathrm{~h}$, cells were treated with 5 -FU $(5,10,20,30$ and $40 \mu \mathrm{M})$ or Olaparib (5 and $10 \mu \mathrm{M})$ or in the indicated combinations for $48 \mathrm{~h}$ or 72 
h. Untreated cells were used as control. A $100 \mathrm{mM}$ stock of 5-FU was prepared in absolute DMSO and stored at $-20^{\circ} \mathrm{C}$. Olaparib stock solution was prepared at $10 \mathrm{mM}$ and stored at $-20^{\circ} \mathrm{C}$. Serial dilutions were prepared in culture medium.

\section{Cell viability}

Cell viability was assessed by MTT assay. HCT116 and HT29 cells were adjusted to a density of $1 \times 10^{4}$ cells and transferred to 96-well plate with a volume of $100 \mu \mathrm{L}$ per well. After treatment, $100 \mu \mathrm{L}$ of MTT solution (5 $\mathrm{mg} / \mathrm{mL}$ ) was added to each well and incubated at $37^{\circ} \mathrm{C}$ for $3 \mathrm{~h}$. Next, cell culture supernatant was removed and $100 \mu \mathrm{L}$ of DMSO was added to each well to dissolve the formazan crystals. Absorbance readings of DMSO extracts were performed in SpectraMax ${ }^{\odot}$ microplate reader (Molecular Devices, LLC, San Jose, CA, USA) at $540 \mathrm{~nm}$.

The mode of interaction (synergy, antagonism or additivity) was determined by calculating the combination index (CI) [36] using CompuSyn software program (CompuSyn, Inc., Paramus, NJ). The degree of interaction between 5-FU and Olaparib was determined by the semiquantitative expression of ranges for antagonism (slight, if CI 1.1-1.2 to very strong, if CI > 10), synergism (slight, moderate, substantial, strong, and very strong), and additive interaction (CI 0.90-1.10) [37].

\section{Clonogenic survival}

Cells were treated as previously described. After $48 \mathrm{~h}$ of exposure to treatments, cells were detached, counted and seeded in 6-well plates at a density of $6 \times 10^{2}$ cells per well in complete medium. Therefore, cells were further incubated for 14 days to allow colony formation. Colonies were fixed with ice-cold methanol for $20 \mathrm{~min}$ and stained with crystal violet $(0.5 \% \mathrm{w} / \mathrm{v})$ solution for 10 $\min$.

\section{Apoptosis determination}

Assessment of cell death induction profile was performed as follows: HCT116 or HT29 cells were seeded in a density of $2 \times 10^{5}$ cells in 6 well-plate $(2 \mathrm{~mL}$ per well) and treated for $48 \mathrm{~h}$ or $72 \mathrm{~h}$. Next, cells were detached and processed according to PE-Annexin V Apoptosis Detection Kit I manufacturer instructions (BD Biosciences). Cells were stained with PE-Annexin $\mathrm{V}$ and 7AAD at room temperature for $15 \mathrm{~min}$ in the dark. Finally, quantification of alive (Annexin ${ }^{-} / 7 \mathrm{AAD}^{-}$), early apoptotic (Annexin ${ }^{+} / 7 \mathrm{AAD}^{-}$) and late apoptotic/necrotic (Annexin $^{+/-} / 7 \mathrm{AAD}^{+}$) cells was carried out on BD FACS Canto $^{\text {тм }}$ II flow cytometer (BD Bioscience, Franklin Lakes, NJ, USA) after 10,000 events acquisition.

\section{Cell cycle perturbation}

Cells were seeded in 6 well-plates $\left(2 \times 10^{5}\right.$ cells/well $)$ and treated as previously described. After treatment, adherent and detached cells were fixed with chilled $80 \%$ ethanol at $-20{ }^{\circ} \mathrm{C}$ for at least $24 \mathrm{~h}$. After removing ethanol, cells were blocked (0.1\% TritonX-100in PBS), stained at $37^{\circ} \mathrm{C}$ for $30 \mathrm{~min}$ in PBS containing $25 \mu \mathrm{g} / \mathrm{mL}$ PI and $50 \mu \mathrm{g} / \mathrm{mL}$ RNAse. Data was acquired in BD FACSCalibur $^{\mathrm{rM}}$ flow cytometer (BD Biosciences, San Diego, CA, USA) after 20.000 events acquisition. The analysis was performed with CELLQuest software (BD Biosciences, San Diego, CA, USA).

\section{DNA damage induction}

DNA damage induction was assessed by Comet Assay. Cells were seeded in 24 well-plates $\left(1 \times 10^{4}\right.$ cells/well $)$ and treated as previously described. At the end of treatment, HCT116 and HT29 cells were detached and $20 \mu \mathrm{L}$ mixed with $100 \mu \mathrm{L} 0.75 \%$ low melting point agarose at $37^{\circ} \mathrm{C}$ and spread on the agarose-coated slides using a coverslip. Coverslips were removed after solidification at $4{ }^{\circ} \mathrm{C}$ for $3 \mathrm{~min}$. The slides were immersed in cold lysis solution at $4{ }^{\circ} \mathrm{C}$ for $24 \mathrm{~h}$. Next, slides were placed in an electrophoresis chamber filled with fresh alkaline buffer (300 mM NaOH, $1 \mathrm{mM}$ EDTA, pH > 13) for $20 \mathrm{~min}$ at $4{ }^{\circ} \mathrm{C}$. Electrophoresis was performed at $300 \mathrm{~mA}$ and $25 \mathrm{~V}$ for $20 \mathrm{~min}$. The slides were washed 3 times with $10 \mathrm{mM}$ Tris buffer ( $\mathrm{pH}$ 7.5) for neutralization. Finally, the slides were stained with silver nitrate and analyzed at 200x magnification using an optical microscope. DNA damage was evaluated using visual classification from 0 (no damage, no tail) to 4 (maximum damage, long tails). One hundred cells were counted for each sample in duplicate slides. The DNA damage index was expressed in arbitrary units (A.U., 0-400).

\section{Adhesion measurements}

Cells were treated for $48 \mathrm{~h}$ as previously described. Next, $3 \times 10^{2}$ cells were then transferred to each well of a 24well plate, and attached cells were counted on a light microscope following 2, 4, 6 and $24 \mathrm{~h}$ of seeding [38]. The adherence capacity (AC) was calculated as follows: $\mathrm{AC}=$ (number of attached/number of plated cells $) \times 100$.

\section{Migration measurements}

Cell motility was assessed in $8-\mu \mathrm{m}$ pore polycarbonate membrane ThinCerts ${ }^{\mathrm{Tm}}$ inserts (Greiner Bio-one Brazil, Americana, SP, Brazil). Cells were treated, detached, counted with trypan blue $0.4 \%$ and then $100 \mu \mathrm{L}$ containing $2 \times 10^{5}$ cells suspended in DMEM/FBS-free medium were added to the top of the insert, except for one, which contained DMEM/10\% SFB as a negative control. In the insert bottom was added DMEM/20\% FBS. Cells were allowed to migrate for $24 \mathrm{~h}$. For quantification, 
non-migrated cells were removed with a swab, the membrane were fixed in methanol for $10 \mathrm{~min}$ and stained in Giemsa solution for $20 \mathrm{~min}$. The membranes were washed with distilled water, removed with a scalpel and the bottom of the membrane was placed up in a slide. The membrane was covered by a coverslip. Migrated cells were counted in five different random fields.

\section{Statistical analyses}

For data quantification, mean values and standard deviation (SD) or standard error of the mean (SEM) were calculated from at least three experimental replicates. Data were analyzed by Graphpad Prism, version 8.0 (Graphpad Instat - NIH, Bethesda, MD, USA) using one or two-way ANOVA (Analysis of Variance) according to the experimental design, followed by Tukey's post-hoc. Two-sided $P$-values $<0.05$ were considered statistically significant.

\section{Results}

Synergism of 5-FU and Olaparib is affected by MMR status in colorectal cancer

First, we examined the anti-proliferative properties of the two single drugs 5-FU and Olaparib and their combination in 1:1, 1:2, 4:1 and 2:1 mixtures by exposing MSI (HCT116) and MSS (Microsatellite stable) (HT29)
CRC cell lines during $48 \mathrm{~h}$ or $72 \mathrm{~h}$ (Fig. 1). We observed a clear reduction of viability in HT29 cell line when treated with 5-FU alone, whereas in HCT116 a significant decrease was observed only for $72 \mathrm{~h}$ treatment at $20 \mu \mathrm{M} 5$-FU. A slight cytotoxic effect for treatment with $10 \mu \mathrm{M}$ of Olaparib alone (mean reduction of $25 \%$ ) was also observed. As expected, HT29 cells were more sensitive to $5-\mathrm{FU}\left(\mathrm{IC}_{50}=36.7 \mu \mathrm{M}, 48 \mathrm{~h}\right)$ than $\mathrm{HCT} 116\left(\mathrm{IC}_{50}=\right.$ $58.7 \mu \mathrm{M}, 48 \mathrm{~h}$ ), which is attributed to the requirement of proficient MMR to achieve 5-FU toxicity [7, 39]. In the combination, Olaparib increased the cytotoxic effect of 5-FU in HCT116 in a dose-dependent manner. While after $48 \mathrm{~h}$ of treatment, this effect was achieved only in combination to $20 \mu \mathrm{M}$ of 5 -FU (mean of $48 \%$ increment in cell death) (Fig. 1a), after prolonged exposure (72 h), it was also observed following exposure to Olaparib in combination to $5 \mu \mathrm{M}$ of 5 -FU (mean increment of $53 \%$ in cell death) (Fig. 1c). Conversely, sensitivity of HT29 to 5-FU was not significantly influenced by Olaparib addition (Fig. 1b and d).

To determine whether the enhanced inhibitory effect observed in HCT116 cells following 5-FU and Olaparib combinations was additive or synergistic, we computed the combination index $(\mathrm{CI})$ for the treatments using the aforementioned Chou [37]. As all interaction indexes of each 5-FU and Olaparib pair ranged from nearly additive

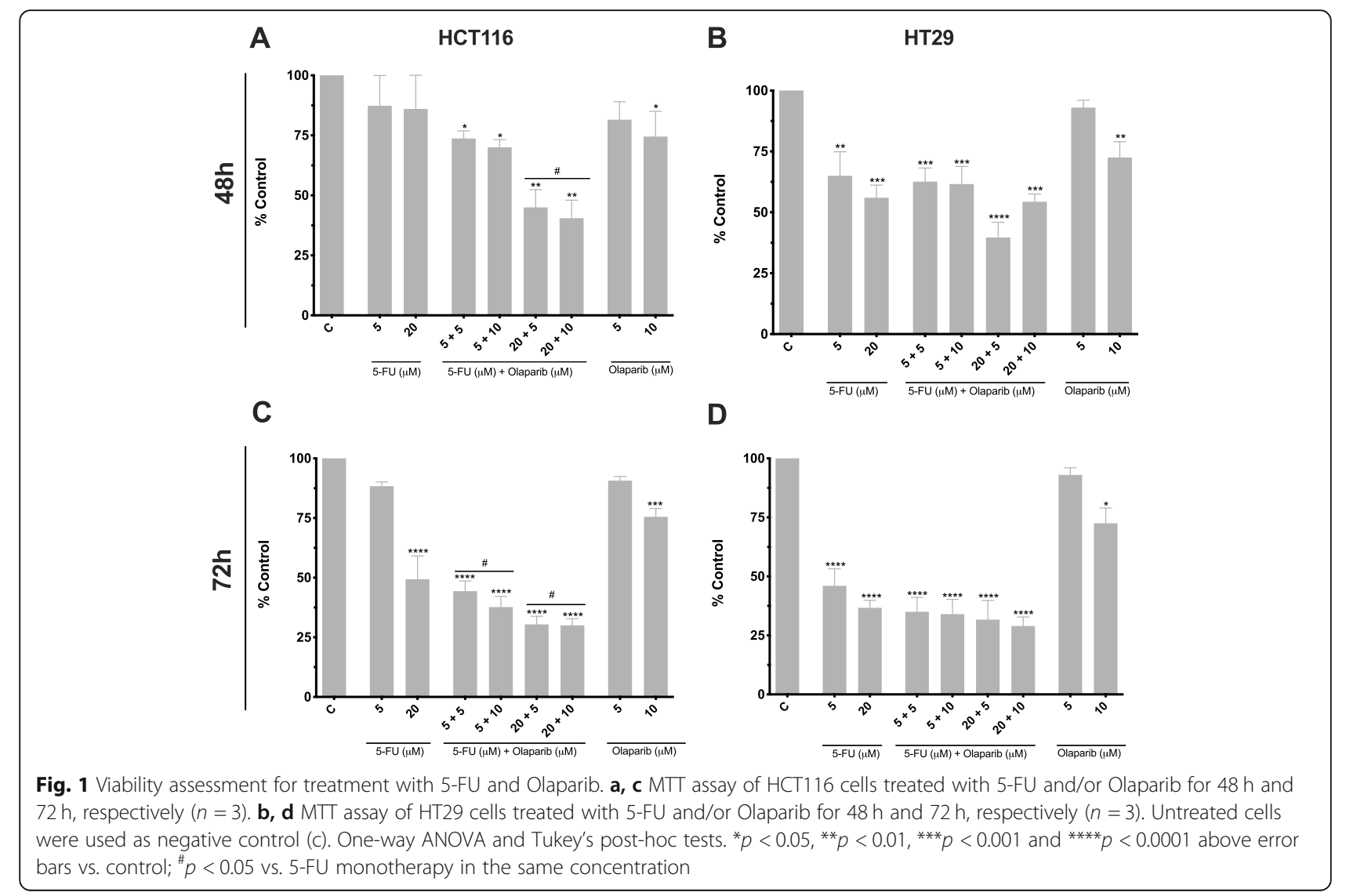


to synergistic interaction (CI 0.3-0.7), we presented these ranges and the $\mathrm{CI}$ for each combination in Fig. 2. After $48 \mathrm{~h}$ treatment, the strongest synergistic inhibitory effect on HCT116 cell growth was reached with $20 \mu \mathrm{M}$ 5 -FU + $5 \mu \mathrm{M}$ Olaparib, and in HT29 with $5 \mu \mathrm{M} 5$-FU + $5 \mu \mathrm{M}$ Olaparib.

Some drugs may possibly cause injury which does not manifest until several cell generations when become lethal. Since the mechanisms by which synergistic effects of 5-FU and Olaparib may induce cell death include DNA damage, mitotic dysfunction and chromosome missegregation [40,41], we investigated to what extent this combination affect clonogenic survival (Fig. 3). The ability of CRC cells treated for $48 \mathrm{~h}$ and $72 \mathrm{~h}$ to form colonies was evaluated after 14 days. In consonance to MTT assay results, HT29 cells were more sensitive than HCT116 to 5-FU alone with no further reduction of viability for the combination with Olaparib (Fig. 3). Addition of Olaparib to 5-FU for $48 \mathrm{~h}$ implicated in a reduction of $70 \%(5 \mu \mathrm{M} 5-\mathrm{FU}+5 \mu \mathrm{M}$ Olaparib) and $97 \%$ $(5 \mu \mathrm{M} 5-\mathrm{FU}+10 \mu \mathrm{M}$ Olaparib) of the HCT116 ability to form colonies in relation to the 5-FU monotherapy (Fig. 3a). Also, $10 \mu \mathrm{M}$ Olaparib monotherapy reduced the number of colony formation in both cell lines after $72 \mathrm{~h}$ (Fig. 3b).

As a stronger synergistic anti-proliferative effect was observed following combination exposure to 5-FU and Olaparib in dMMR HCT116 cells, we aimed to determine whether the decreased cell survival was related to apoptosis. Combinations of $5 \mu \mathrm{M}$ or $20 \mu \mathrm{M} 5$-FU + $10 \mu \mathrm{M}$ Olaparib increased the population of HCT116 apoptotic cells after treatment of $48 \mathrm{~h}$ (increase of 21 and $38 \%$, respectively) and $72 \mathrm{~h}$ (increase of 41 and $28 \%$, respectively). However, none of the combinations enhanced the apoptotic population in HT29 cells in relation to the 5-FU alone at these time points (Fig. 4). Hence, our data suggest that, when Olaparib is combined with 5-FU, the apoptosis induction is enhanced in dMMR HCT116, but not in pMMR HT29 CRC cells. Interestingly, single administration of $10 \mu \mathrm{M}$ Olaparib increased apoptosis in relation to the untreated control again only in HCT116 (Fig. 4) after 48 and $72 \mathrm{~h}$.

\section{Olaparib treatment alone or in combination with 5-FU leads to generation of DNA strand breaks in MMR- proficient colon cancer cells}

To gain insights into the mechanisms underlying the apparent synergistic activity of 5-FU and Olaparib in the studied CRC cell lines, we examined the genome integrity using single cell gel electrophoresis (comet) assay. As can be seen on Fig. 5b no significant increase in the DNA strand breaks was observed in the MMR deficient HCT116 cell line. However, exposure of pMMR HT29 cells to 5 -FU in combination with 5 or $10 \mu \mathrm{M}$ of Olaparib induced DNA strand breaks after $12 \mathrm{~h}$ (Fig. 5a).

Unexpectedly, we identified higher basal DNA damage in HCT116 cells in comparison to HT29.

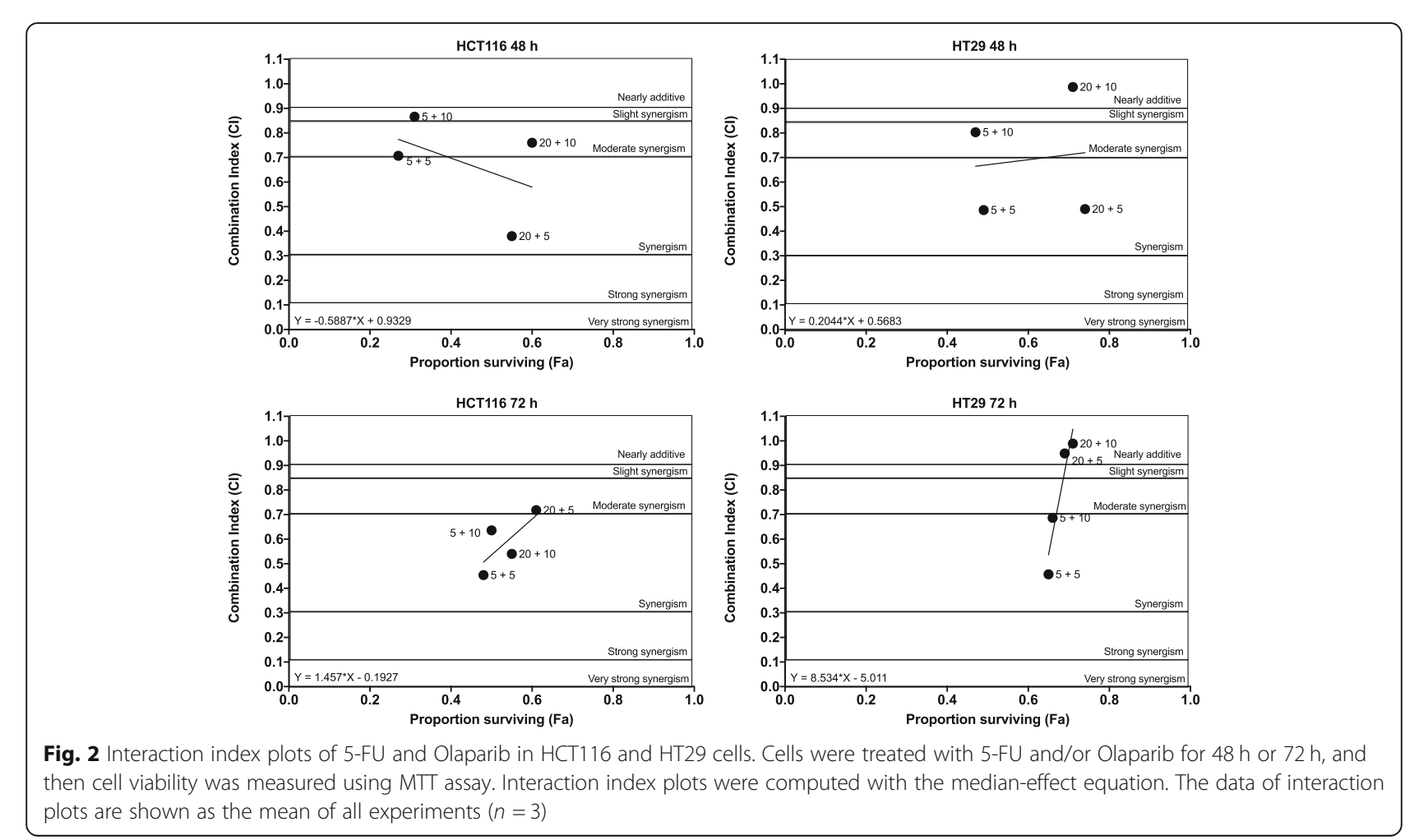




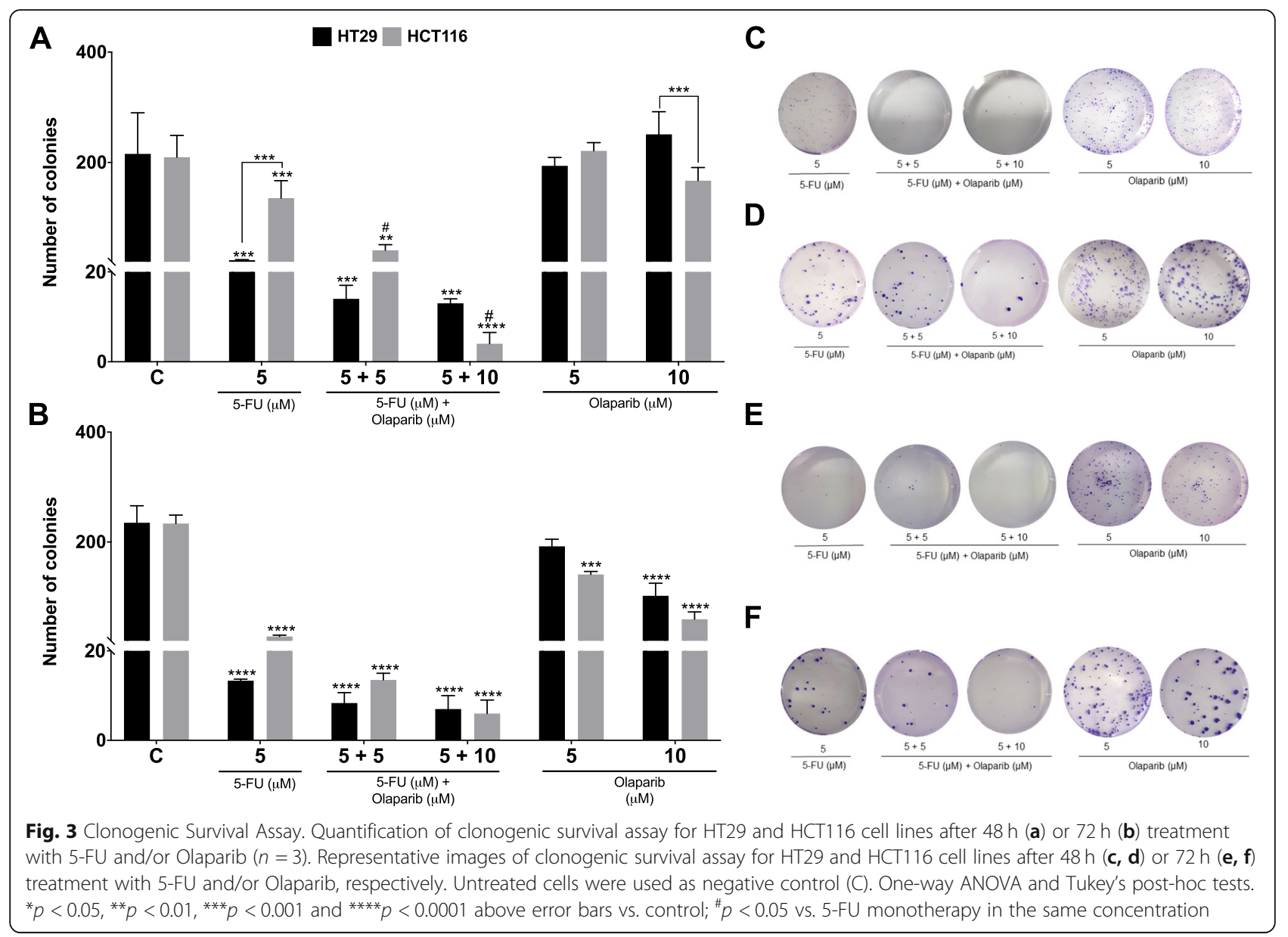

Olaparib induces polyploidy and promotes G2/M arrest in the combined treatment with 5-FU in MMR-deficient colon cancer cells

Whereas the unrepaired DNA damage leads to senescence or apoptosis in drug-responsive cancer cells, loss of cell cycle checkpoints and increase of DNA damage tolerance allows subset of cancer cells perpetuate harmful mutations [42]. Therefore, we investigated whether cell cycle perturbations contributed to the cell death induction or growth inhibition by flow cytometry after 48 $h$ of treatment (Fig. 6). It has been postulated that PARPis-induced cytotoxicity requires disruption of both replication and mitosis machinery. Replication blockage may be a consequence of entrapment and accumulation of inactive PARP1 as a result of PARP inhibition [43].

No significant cell cycle alterations are detected upon administration of 5-FU and Olaparib in HT29 CRC cells (Fig. 6a). Inversely, combined Olaparib and 5-FU treatment significantly increased the percentage of HCT116 cells in the $\mathrm{G} 2 / \mathrm{M}$ phase in relation to the 5-FU alone (Fig. 6a). Strikingly, we detected a specific cell cycle interference following single Olaparib treatment, as a slight increase in the G2/M population of both cell lines and polyploidy induction only in MMR deficient HCT116 cells (Fig. 6c).

\section{Olaparib monotherapy impairs adhesion and migration} capacities in MMR-proficient colon cancer cells

Cell attachment is necessary for adherent cells to survive, proliferate and establish metastatic niches. For the best of our knowledge, this is the first study to explore the effects of 5-FU and Olaparib combination with regard to CRC cells adhesion and migration abilities. Thus, we treated both cell lines for $48 \mathrm{~h}$ and investigated adhesion capacity after 2, 4, 6, 12 and 24 h (Fig. 7a). Concerning HT29 cells, we observed two patterns, according to the reduction of cells attached after $24 \mathrm{~h}$ in comparison to controls: (1) intermediate (adhesion capacity was reduced to 50\%): Olaparib treated cells; and (2) low (adhesion capacity was reduced to $30 \%$ ): cells treated with $5 \mu \mathrm{M} 5$-FU alone or in combination with olaparib (Fig. 7a).

Unexpectedly, we observed that Olaparib monotherapy reduced adhesion capacity of HT29 cells, but no effect was exerted in HCT116 cells (Fig. 7b). In fact, this observation led us to investigate the metastatic potential of these cells by transwell assay (Fig. 7c and d). While $5 \mu \mathrm{M}$ 

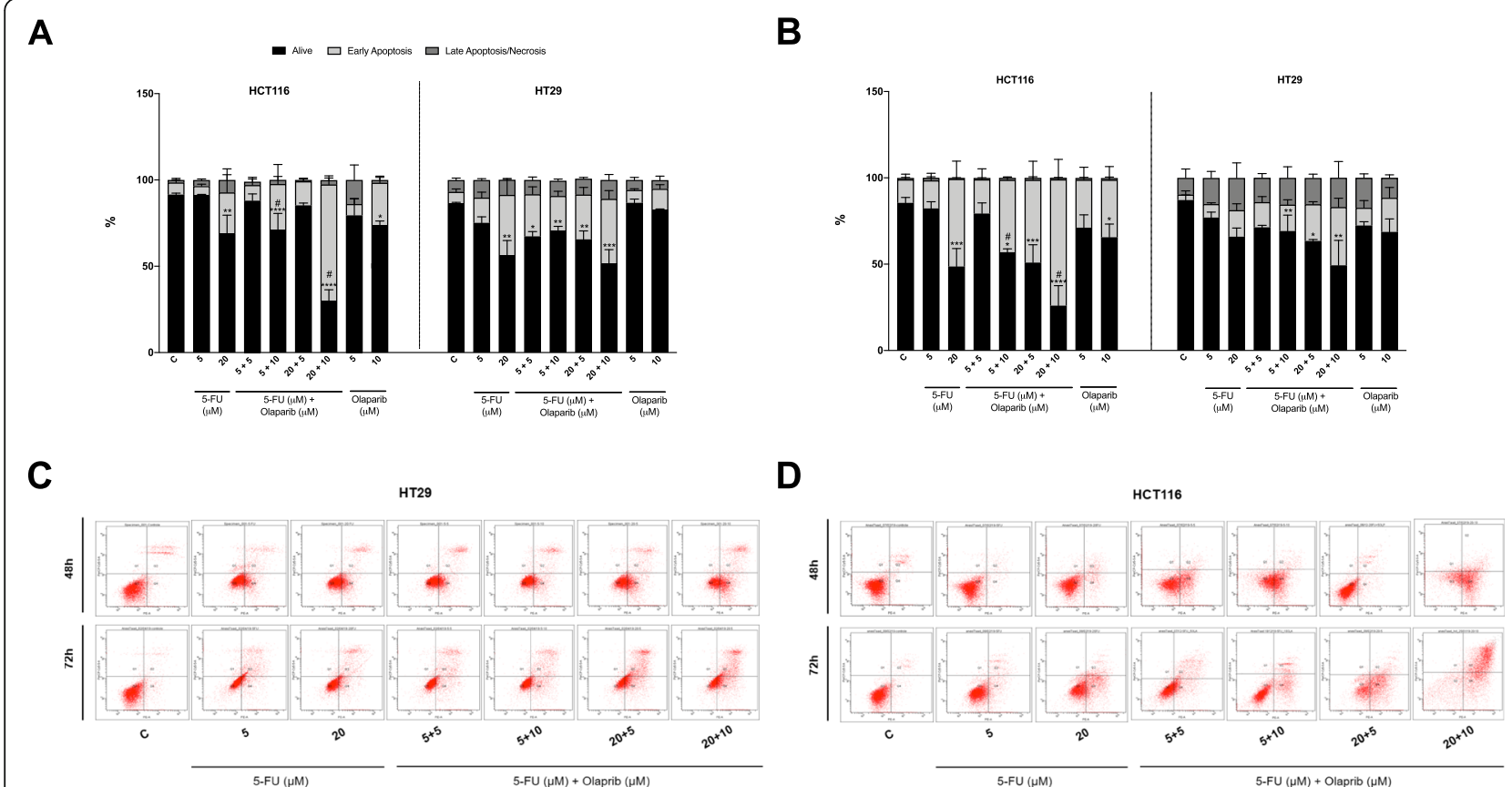

Fig. 4 Apoptosis detection. Annexin-V and 7AAD staining was quantified by flow cytometry for HCT116 and HT29 treated with 5-FU and/or Olaparib for $48 \mathrm{~h}(\mathbf{a})$ or $72 \mathrm{~h} \mathrm{(b)}(n=3)$. Representative dotplots showing cell distribution between compartments in flow cytometry analysis using Annexin-V and 7-AAD staining for HT29 cells (c) or HCT116 cells (d) treated with 5-FU and/or Olaparib for 48 and 72 h. Untreated cells were used as negative control (c). One-way ANOVA and Tukey's post-hoc tests. ${ }^{*} p<0.05,{ }^{* *} p<0.05,{ }^{* * *} p<0.001$ and ${ }^{* * * *} p<0.0001$ above error bars vs. control; ${ }^{\#} p<0.05$ vs. 5-FU monotherapy in the same concentration

5-FU did not affected HT29 cells migration ability, Olaparib addition to 5 -FU resulted in a reduction of $30 \%$ in the number of migrated cells.

\section{Discussion}

Conventional cancer regimens rely on chemotherapy, which generally exert its effects by inducing DNA damage or disrupting the mitotic machinery. While 5-FU has been the backbone of sporadic CRC treatment since 1960, advances in molecular comprehension, including the role of MMR deficiencies in response to therapy, brought to light a mechanism for 5-FU resistance. Alternatively, benefit may arise from combination therapy based on agents with non-overlapping mechanisms to reach synergistic or additive mechanism to overcome 5FU resistance in the MMR deficient subset of colorectal tumors.

PARPis monotherapy has encountered its greatest efficacy in solid tumors with intrinsic HRR deficiencies. However, with the advances in the comprehension of PARPi sensitive-determining factors emerged the possibility of combinations with DNA damaging agents. Based on the fact that chemotherapy can increase DNA damage and PARPis can diminish the ability of PARP enzymes to repair DNA damage [44], it seems counterintuitive to explore these combinations. Thus, we hypothesized that causing DNA damage (via 5-FU) and impairing DNA damage response (via PARP inhibition) could be a potential strategy to recreate 5 -FU sensitivity in colorectal tumors with MMR deficient background.

It has been postulated that apoptotic signaling cascade could be activated by the direct interaction of the damage-bound MMR heterodimers, hMutS $\alpha$ and hMutL $\alpha$, and proteins of the ATR-Chk1 pathway. Consequently, it is thought that MMR acts as a DNA damage sensor, which has been referred as the "direct signaling model" [45, 46]. In this model, MMR role is beyond DNA repair, as it participates in signal transduction for cell death. Indeed, MMR protein-dependent pro-death signaling in response to various DNA-damaging agents have been well characterized, including 5-FU [11]. FU:G and FdUrd:G mismatches caused by 5 -FU incorporation into DNA during replication are recognized by $\mathrm{MSH} 2$, inducing a futile cycle of repair [47]. Continuous attempts to daughter strand excision ultimately lead to disruption of DNA replication, which activates a MMRdependent ATR-Chk1 signaling [48]. Contrariwise, in the absence of a functional MMR (particularly as a result of $h M L H 1$ loss, as in HCT116), caspase-3 cleavage does not occur and apoptosis cascade is not triggered [49].

Besides $h M L H 1, H C T 116$ cells also lack $h M S H 3$ and have low levels of ATM protein expression in comparison to other CRC cell lines [34, 35]. CRC harboring frameshift/nonsense mutation in $h M S H 3$ accounts for 

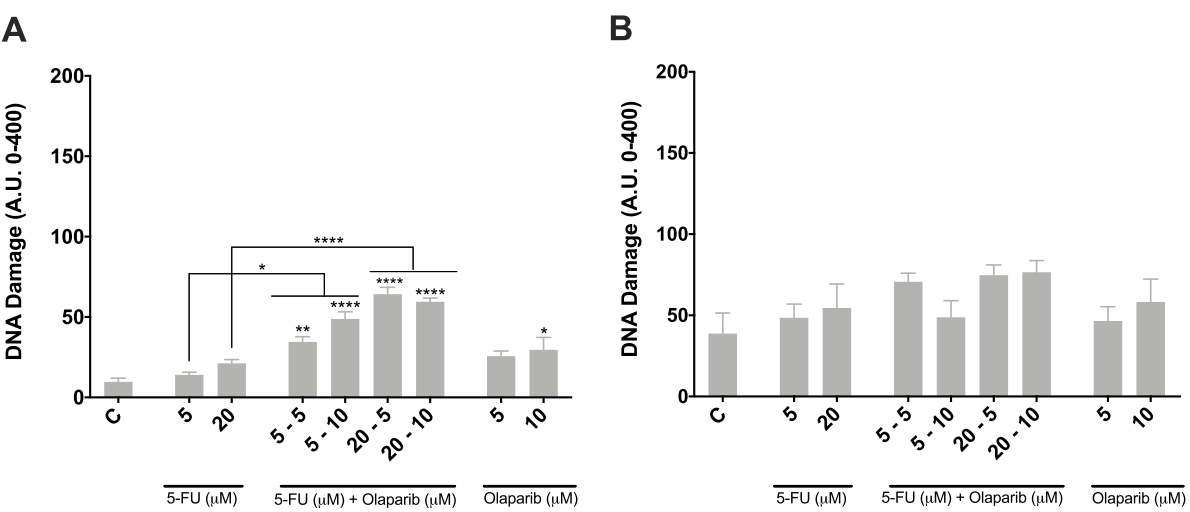

Fig. 5 DNA damage index. DNA damage quantification by alkaline comet assay was performed immediately after $12 \mathrm{~h}$ of treatment with 5 -FU and/or Olaparib in HT29 (a) and HCT116 (b) and cell lines $(n=3)$. Untreated cells were used as negative control. ${ }^{*} p<0.05,{ }^{* *} p<0.01,{ }^{* * *} p<0.001$ and ${ }^{* * *} p<0.0001$ above error bars vs. control

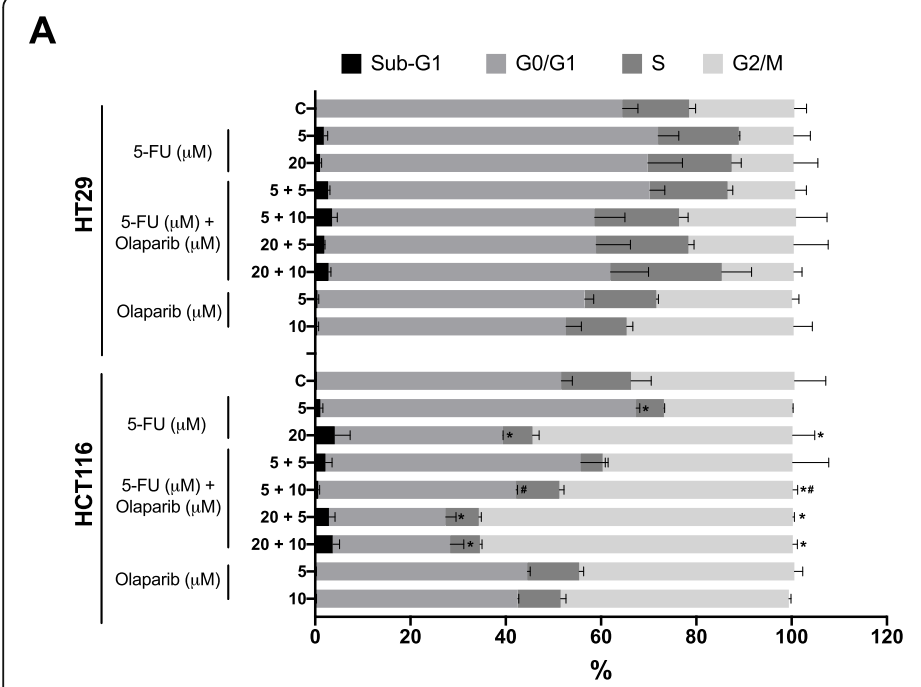

C

B
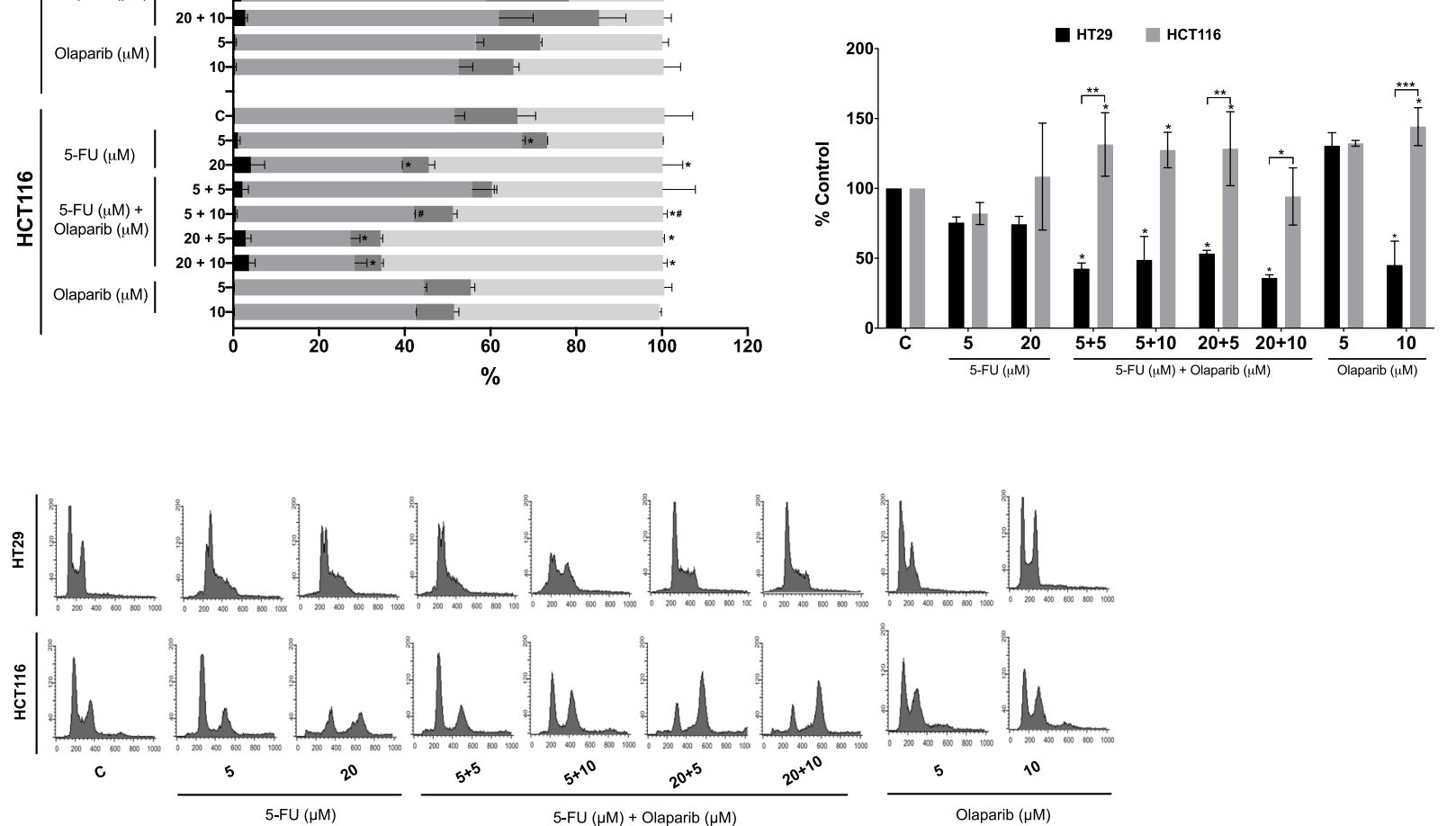

Fig. 6 Cell cycle analysis. a Quantification of cell cycle profile analyzed by flow cytometry in HT29 and HCT116 cell lines after $48 \mathrm{~h}$ treatment with 5 -FU and/or Olaparib $(n=3)$. ${ }^{*} p<0.05$ above error bars vs. controls at the same cell cycle phase; $\# p<0.05$ vs. 5 M 5-FU in monotherapy. $\mathbf{b}$ Representative histograms of cell cycle profile in HT29 and HCT116 cell lines after $48 \mathrm{~h}$ treatment with 5-FU and/or Olaparib. c Polyploidy (>4n) population accumulation following $48 \mathrm{~h}$ treatment with 5 -FU and/or Olaparib Untreated cells were used as negative control (c). ${ }^{*} p<0.05,{ }^{* *} p<$ 0.01 and ${ }^{* *} p<0.001$ above error bars vs. controls. Two-way ANOVA and Tukey's post-hoc tests 


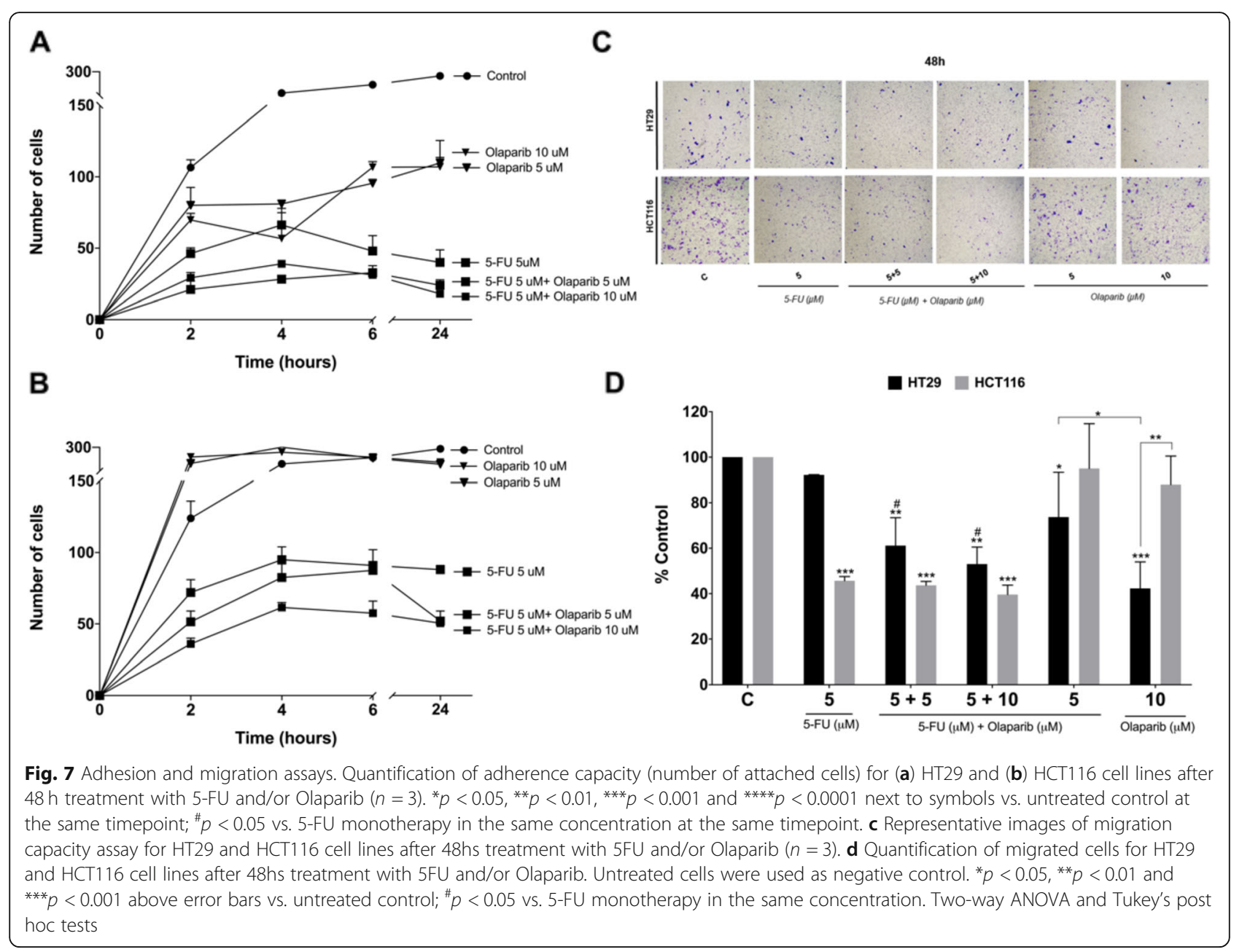

almost 50\% of all MMR-deficient CRC [50], which brings clinical relevance to this molecular phenotype. Some hMSH3-deficient tumors behave like HRRdeficient tumors and present replication fork stress, since MSH3 is involved in DSBs and interstrand crosslinks (ICLs) repair [51]. Consequently, $h M S H 3$-deficient tumors are potentially sensitive to PARPis [26]. However, few articles have investigated the effects of in vitro combinations of PARPis and 5-FU in colon cancer cell lines, with controversial results [31,32].

When DNA damage occurs in the presence of a PARP inhibitor, such as Olaparib, PARP1 binds to damage sites and remains tightly bound or trapped onto the chromatin. That is whereby PARP inhibitors act as DNA poisons by trapping PARP on damaged DNA, resulting in cytotoxic PARP-DNA complexes. These complexes are much more cytotoxic than merely unrepaired SSBs, since PARylation is inhibited, and PARP1 remains bound to the lesion, which leads to stalled replication fork $[24,52]$. The PARP1 cannot proceed with its role in fork stabilization and recruitment of the fork protection machinery $[48,53]$. Consequently, replication fork collapses into DSBs, ultimately leading to cell death.

Our data for the combination treatment with 5-FU and Olaparib in the dMMR HCT116 cell line do not indicate increase in DNA strand breaks formation (Fig. $5 b)$. So, the apoptosis induction in this cell line after PARP inhibition (Fig. 4b) should rely on other mechanism, different from replication fork collapse and DSBs formation. Instead, the observed accumulation of cells in G1 phase after $5 \mu \mathrm{M} 5 \mathrm{FU}$ treatment, already described for the HCT116 cells [54], changes to G2 arrest after the combined treatment with $10 \mu \mathrm{M}$ Olaparib (Fig. 6a). In this respect, it was shown that ATR inhibition potentiates cytotoxic effects of PARP inhibition by forced mitotic entry in cancer cells with deficient HRR [55]. The used single DNA fiber analysis in these circumstances showed that ATR inhibition does not increase replication fork degradation but accelerate mitotic entry, thus leading to chromatin bridges and lagging chromosomes formation. Moreover, in BRCA-mutant ovarian cancer cells, addition of ATRi or CHK1i released the cells from 
G2 phase arrest induced by PARPi causing premature mitotic entry resulting in increased chromosomal aberrations and apoptosis [56]. So, taken together our results in HCT116 cell line, having in mind its ATR-Chk1 signaling deficiency due to $h M L H 1$ loss, and the $h M S H 3$ mutation (i.e. HRR-deficient like phenotype), indicate that PARP inhibition leads to G2 arrest, premature mitosis entry and apoptosis induction in a combined treatment with 5 -FU.

The 5-FU treatment sensitizes colorectal cancer cells towards DSBs and reduces HRR-mediated repair, which provide a biological rationale for its use as chemo- and radiosensitizer $[13,57]$. While PARPis are synthetic lethal in HRR-deficient tumors, accumulating evidence suggests that PARylation is involved in both SSBs and DSBs repair [58]. However, whether MSI-tumors may also be susceptible to PARP inhibition is still a matter of discussion. Recently, a phase II trial reported that Olaparib monotherapy did not affect patient outcomes regardless of microsatellite status [59]. However, MSIinduced mutations in the DNA repair genes MRE11 and ATM sensitizes gastrointestinal cancer cells to PARP inhibition [28, 60]. To date, chemical inhibition of PARP leads to replication fork collapse or accelerated fork progression that generates SSBs and DSBs [61, 62]. Since PARP1 promotes the repair of non-toxic single-strand DNA breaks, which are converted into potentially toxic DSBs during S-phase [63], the synergistic effect of the Olaparib and 5-FU cytotoxicity observed in HT29, could be attributed to increase in the DNA strand breaks induction.

While HT29 cells have chromosomal instability (CIN), HCT116 present MSI due to MMR deficiency. As aforementioned, HCT116 cells lack both $h M L H 1$ and $h M L H 3$. It has been suggested that $h M L H 3$ plays a prominent role to elicit DSBs repair and DNA-damage response [26]. Actually, it was demonstrated that $h M S H 3$ silencing results in a 2 -fold increase of DSBs [64]. In addition to the fact that MSI is associated with downregulation of MRE11 in colon cancer cells, which is essential for optimal signaling of ATM in response to DSBs [65], HCT116 cells also carry a mutation (c3380C > T) in one ATM allele, affecting ATM expression to half of normal [28]. This meets previous evidence in mantle cell lymphomas, gastric and colorectal tumors harboring mutations in ATM that result in loss or decrease of protein function and higher sensitivity to PARPis [28, 60, 66]. So, additional studies are needed in order to extend the observed synergistic effect of Olaparib and 5-FU to dMMR CRC cell lines with different genetic background.

While the increase in G2/M HT29 cells might be correlated with the DNA strand-breaks induction (Fig. 6a) and activation of DNA damage response, the mitotic arrest and polyploidy in HCT116 cells could be attributed to premature mitosis entry as discussed above. The cellular responses to mitotic delay are widely variable and appear to depend on an intriguing molecular competition between pathways leading to either apoptosis or slippage. Polyploid tumor cells are created by cytotoxic and targeted therapies, and elevated ploidy is likely to significantly increase during therapy [67]. However, since PARPis have been implicated in accumulation of polyploidy cells and in accordance to the hypothesis that polyploidy can result from mitotic defects, it may points out to a mechanism by which PARPis induce cell death [68]. By acting on replicating cells, Olaparib entraps PARP1 and obstructs replication fork progression, resulting in loss of sister chromatid cohesion in G2 cells [43]. Additionally, MLH1 (here functional only in HT29 cells) is known to be involved in DNA damage-induced checkpoint, favoring G2/M arrest [69].

Despite the low synergistic effect on cytotoxicity in MMR proficient HT29 cells, the combination of Olaparib and 5-FU increased DNA damage induction and decreased adhesion capacity of these cells. Cancer cells can undergo epithelial to mesenchymal transition (EMT), incorporating an invasive cell phenotype that can drive metastasis and enter a drug refractory state due to epigenetic reprograming. One of the mechanisms related to EMT facilitation is polyploidy, as giant polyploid tumor cells gain a mesenchymal phenotype [70]. In accordance to this concept, following Olaparib treatment in HT29 cells we observed the reduction of adhesion and migration capacities as at the same time the polyploid population accumulation was prevented. Contrariwise, HCT116 polyploid population was remarkably enriched after combination treatment with 5-FU and Olaparib, but without changes in the metastatic potential, which is already decreased by the 5-FU. Thus, if a possible MMR-status associated polyploidy induction in response to the treatment exits, it remains to be clarified in further investigations.

These observations are particularly relevant regarding a potential new role of Olaparib monotherapy in MMR proficient colorectal tumors. Despite we observed a reduction in cell viability and clonogenic survival following Olaparib monotherapy treatment irrespective to MSI status (Figs. 1 and 3), decrease of the adhesion and migration capacities was observed only in MMR proficient MSS cell line. Recent study, including 99 MSS cell lines did not show association between the sensitivity to Olaparib and specific consensus molecular subtype (CMS) or mutations in $K R A S$ and $B R A F$, commonly accessed in CRC [71]. Moreover, two cell lines derived from different locations of the same patient, showed resistance (SW480, primary tumor) and sensitivity (SW620, lymph node metastasis) to Olaparib. However, most of the cell 
lines sensitive to Olaparib showed cross-sensitivity to oxaliplatin and non-functional HRR. Also, the data revealed that mutational signatures correlated to $H R$ defects, BRCAness or HRR diagnostic assays do not completely discriminate PARPi susceptible CRC tumors but DNA repair functional tests. The cross-sensitivity between oxaliplatin and Olaparib was also confirmed in patient-derived organoids, and maintenance therapy with Olaparib was suggested for metastatic CRC patients with HRR deficient tumors that respond to first-line FOLFOX-chemotherapy [71]. Hence, Olaparib and 5-FU combination has stronger synergistic cytotoxic effect specifically to MMR deficient MSI CRC, while Olaparib monotherapy may emerge as a maintenance therapy for unresectable and metastatic MMR proficient MSS CRC.

\section{Conclusions}

Here, we provide a rational for the inclusion of the PARP inhibitor Olaparib in two new therapeutic approaches for CRC: (1) in combination with 5-FU for $\mathrm{dMMR} / \mathrm{MSI}$ CRC and (2) as monotherapy for pMMR/ MSS CRC. Our results showed the 5-FU cytotoxicity enhancement by Olaparib in dMMR HCT116 colon cancer cells. The observed synergistic effect of the combined treatment in these cells could be attributed to impaired adhesion ability and apoptosis induction. This is particularly relevant since MMR-deficient cells are more resistant to 5-FU, and Olaparib addition can result in 5-FU dose reduction. Although, further studies are needed to confirm the observed effect in dMMR CRC cell lines with different genetic background. For the first time, we observed DNA damage induction and impairment of adhesion and migration capacities following Olaparib in monotherapy treatment only in MMR proficient cells. Therefore, the combined Olaparib and 5-FU treatment could benefit patients with non-metastatic dMMR/MSI colorectal tumors, while Olaparib monotherapy may have a role as a maintenance therapy for advanced MMR proficient/MSS CRC.

\section{Abbreviations \\ 5-FU: 5-fluorouracil (5-FU); BER: Base Excision Repair; Cl: Combination index; CIN: Chromosomal instability; CRC: Colorectal cancer; dMMR: MMR deficient pMMR MMR proficient; DSBs: Double-stranded DNA breaks; EMT: Epithelial to mesenchymal transition; h: Hours; HRR: Homologous Recombination Repair; ICLs: Interstrand crosslinks; MMR: Mismatch Repair; MSI: Microsatellite Instability; MSS: Microsatellite stable; PARP1: Poly-(ADP-ribose) polymerase 1; PARPis: PARP inhibitors; pMMR: Proficient MMR; SSBs: Single-strand DNA breaks; TS: Thymidylate synthase; UDG: Uracil-DNA glycosylase}

\section{Acknowledgements}

Not applicable.

\section{Authors' contributions}

HCG: development of the study concept, investigation of viability tests, type of cell death, cell cycle profile, comet assay, wrote the original draft of manuscript; LJN: investigation of cell adhesion; PBG: investigation of type of cell death, cell cycle profile and transwell assay; PVCG: investigation of comet assay; TNG: data interpretations, review and editing of manuscript; NML: development of study concept, statistical analysis; wrote the original draft; review and editing; supervision. JS: development of study concept; resources, funding acquisition, review and editing; supervision. The author(s) read and approved the final manuscript.

\section{Funding}

This research was supported by FAPERGS (Fundação de Amparo à Pesquisa do Estado do Rio Grande do Sul, Porto Alegre, Brazil- Grant N. 16/25510000 473-0; 17/2551-0001 459-6;), CNPq (Conselho Nacional de Desenvolvimento Científico e Tecnológico, Brasília, Brazil - Grant N. 423039/2016-4), and CAPES (Coordenação de Aperfeiçoamento de Pessoal de Nível Superior, Brasília, Brazil). HC Gloria received a fellowship from CAPES.

\section{Availability of data and materials}

The datasets used and/or analysed during the current study are available from the corresponding author on reasonable request.

\section{Declarations}

Ethics approval and consent to participate

Not applicable.

\section{Consent for publication}

Not applicable.

Competing interests

Not applicable.

\section{Author details}

${ }^{1}$ Laboratory of Genetic Toxicology, Federal University of Health Sciences of Porto Alegre (UFCSPA), Sarmento Leite st 245, Porto Alegre, RS, Brazil. ${ }^{2}$ Cardiology Institute of Rio Grande do Sul/ University Foundation of Cardiology (ICFUC), Porto Alegre, RS, Brazil.

Received: 9 February 2021 Accepted: 12 April 2021

Published online: 22 April 2021

\section{References}

1. Bray F, Ferlay J, Soerjomataram I, Siegel RL, Torre LA, Jemal A. Global cancer statistics 2018: GLOBOCAN estimates of incidence and mortality worldwide for 36 cancers in 185 countries. CA Cancer J Clin. 2018;68(6):394-424. https://doi.org/10.3322/caac.21492.

2. Van Cutsem E, Cervantes A, Adam R, Sobrero A, Van Krieken JH, Aderka D, et al. ESMO consensus guidelines for the management of patients with metastatic colorectal cancer. Ann Oncol. 2016;27(8):1386-422. https://doi. org/10.1093/annonc/mdw235.

3. Hammond WA, Swaika A, Mody K. Pharmacologic resistance in colorectal cancer: a review. Ther Adv Med Oncol. 2016;8(1):57-84. https://doi.org/10.11 77/1758834015614530.

4. Guinney J, Dienstmann R, Wang X, de Reyniès A, Schlicker A, Soneson C, et al. The consensus molecular subtypes of colorectal cancer. Nat Med. 2015:21(11):1350-6 Available from: http://www.nature.com/doifinder/10.103 8/nm.3967.

5. Punt CJA, Koopman M, Vermeulen L. From tumour heterogeneity to advances in precision treatment of colorectal cancer. Nat Rev Clin Oncol. 2017;14(4):235-46. Available from:. https://doi.org/10.1038/nrclinonc.2016.171.

6. Fearon ER. Molecular genetics of colorectal Cancer. Annu Rev Pathol Mech Dis. 2011;6(1):479-507 Available from: http://www.annualreviews.org/doi/a bs/10.1146/annurev-pathol-011110-130235.

7. Sargent DJ, Marsoni S, Monges G, Thibodeau SN, Labianca R, Hamilton SR, et al. Defective mismatch repair as a predictive marker for lack of efficacy of fluorouracil-based adjuvant therapy in colon cancer. J Clin Oncol. 2010; 28(20):3219-26. https://doi.org/10.1200/JCO.2009.27.1825.

8. Sinicrope FA, Foster NR, Thibodeau SN, Marsoni S, Monges G, Labianca R, et al. DNA mismatch repair status and colon cancer recurrence and survival in clinical trials of 5-fluorouracil-based adjuvant therapy. J Natl Cancer Inst. 2011;103(11):863-75. https://doi.org/10.1093/jnci/djr153.

9. André T, De Gramont A, Vernerey D, Chibaudel B, Bonnetain F, TijerasRaballand $A$, et al. Adjuvant fluorouracil, leucovorin, and oxaliplatin in stage II to III colon cancer: updated 10-year survival and outcomes according to 
BRAF mutation and mismatch repair status of the MOSAIC study. J Clin Oncol. 2015;33(35):4176-87. https://doi.org/10.1200/JCO.2015.63.4238.

10. Gavin PG, Colangelo LH, Fumagalli D, Tanaka N, Remillard MY, Yothers G, et al. Mutation profiling and microsatellite instability in stage II and III colon cancer: an assessment of their prognostic and oxaliplatin predictive value. Clin Cancer Res. 2012;18(23):6531-41. https://doi.org/10.1158/1078-0432. CCR-12-0605.

11. Iwaizumi M, Tseng-rogenski S, Carethers JM. DNA mismatch repair proficiency executing 5-fluorouracil cytotoxicity in colorectal cancer cells. Cancer Biol Ther. 2011;12(8):756-64.

12. Wyatt MD, Wilson III DM. Participation of DNA repair in response to 5fluorouracil. Cell Mol Life Sci. 2009;66(5):788-99. https://doi.org/10.1007/ s00018-008-8557-5.

13. Kunz C, Focke F, Saito Y, Schuermann D, Lettieri T, Selfridge J, et al. Base Excision by Thymine DNA Glycosylase Mediates DNA-Directed Cytotoxicity of 5-Fluorouracil. PLoS Biol. 2009;7(4):e91. https://doi.org/10.1371/journal. pbio.1000091.

14. Sengupta T, Torgersen ML, Kassahun H, Vellai T, Simonsen A, Nilsen H. Base excision repair AP endonucleases and mismatch repair act together to induce checkpoint-mediated autophagy. Nat Commun. 2013;4:2674. https:// doi.org/10.1038/ncomms3674.

15. Sjolund A, Nemec AA, Paquet N, Prakash A, Sung P, Doublié S, et al. A germline polymorphism of thymine DNA glycosylase induces genomic instability and cellular transformation. PLoS Genet. 2014;10(11):e1004753. https://doi.org/10.1371/journal.pgen.1004753.

16. Polo LM, Xu Y, Hornyak P, Garces F, Zeng Z, Hailstone R, et al. Efficient single-Strand break repair requires binding to both poly (ADP-Ribose) and DNA by the central BRCT domain of XRCC1. Cell Rep. 2019;26(3):573-581.e5. Available from:. https://doi.org/10.1016/j.celrep.2018.12.082.

17. Patel AG, Sarkaria JN, Kaufmann SH. Nonhomologous end joining drives poly(ADP-ribose) polymerase (PARP) inhibitor lethality in homologous recombination-deficient cells. Proc Natl Acad Sci U S A. 2011;108(8):3406-11. https://doi.org/10.1073/pnas.1013715108.

18. Szigyarto CA, Johansson F, Uhle M, Stro CE, Erixon K, Helleday T. Poly (ADPribose) polymerase (PARP) is not involved in base excision repair but PARP inhibition traps a single-strand intermediate. Nucleic Acids Res. 2011;39(8): 3166-75. https://doi.org/10.1093/nar/gkq1241.

19. Venkitaraman AR. Cancer suppression by the chromosome custodians, BRCA1 and BRCA2. Science (80- ). 2014;343(6178):1470-5.

20. Robson M, Im SA, Senkus E, Xu B, Domchek SM, Masuda N, et al. Olaparib for metastatic breast cancer in patients with a germline BRCA mutation. N Engl J Med. 2017;377(6):523-33. https://doi.org/10.1056/ NEJMoa1706450.

21. Franzese E, Centonze S, Diana A, Carlino F, Guerrera LP, Di Napoli M, et al. PARP inhibitors in ovarian cancer. Cancer Treat Rev. 2019;73(October 2018): 1-9. Available from:. https://doi.org/10.1016/j.ctrv.2018.12.002.

22. Ledermann J, Harter P, Gourley C, Friedlander M, Vergote I, Rustin G, et al. Olaparib maintenance therapy in platinum-sensitive relapsed ovarian cancer. N Engl J Med. 2012;366(15):1382-92. https://doi.org/10.1056/ NEJMoa1105535.

23. Lord CJ, Ashworth A. PARP inhibitors: the first synthetic lethal targeted therapy. Science. 2017;355(6330):1152 Available from: https://www.ncbi.nlm. nih.gov/pmc/articles/PMC6175050/.

24. Murai J, Pommier Y. PARP trapping beyond homologous recombination and platinum sensitivity in cancers. Annu Rev Cancer Biol. 2019;3(1):131-50. https://doi.org/10.1146/annurev-cancerbio-030518-055914.

25. Gaymes TJ, Mohamedali AM, Patterson M, Matto N, Smith A, Kulasekararaj A, et al. Microsatellite instability induced mutations in DNA repair genes CtIP and MRE11 confer hypersensitivity to poly (ADP-ribose) polymerase inhibitors in myeloid malignancies. Haematologica. 2013;98(9):1397-406. https://doi.org/10.3324/haematol.2012.079251.

26. Takahashi M, Koi M, Balaguer F, Boland CR, Goel A. MSH3 mediates sensitization of colorectal cancer cells to cisplatin, oxaliplatin, and a poly(ADP-ribose) polymerase inhibitor. J Biol Chem. 2011;286(14):12157-65. https://doi.org/10.1074/jbc.M110.198804

27. McPherson LA, Shen Y, Ford JM. Poly (ADP-ribose) polymerase inhibitor LT626: sensitivity correlates with MRE11 mutations and synergizes with platinums and irinotecan in colorectal cancer cells. Cancer Lett. 2014;343(2): 217-23. Available from:. https://doi.org/10.1016/j.canlet.2013.10.034.

28. Wang C, Jette N, Moussienko D, Bebb DG, Lees-Miller SP. ATM-deficient colorectal Cancer cells are sensitive to the PARP inhibitor Olaparib. Transl
Oncol. 2017;10(2):190-6. Available from:. https://doi.org/10.1016/j.tranon.201 7.01.007.

29. Abu-Sanad A, Wang Y, Hasheminasab F, Panasci J, Noë A, Rosca L, et al. Simultaneous inhibition of ATR and PARP sensitizes colon cancer cell lines to irinotecan. Front Pharmacol. 2015;6:147. https://doi.org/10.3389/fphar.201 5.00147.

30. Li LS, Morales JC, Veigl M, Sedwick D, Greer S, Meyers M, et al. DNA mismatch repair (MMR)-dependent 5-fluorouracil cytotoxicity and the potential for new therapeutic targets. Br J Pharmacol. 2009;158(3):679-92. https://doi.org/10.1111/j.1476-5381.2009.00423.x.

31. Shelton JW, Waxweiler TV, Landry J, Gao H, Xu Y, Wang $L$, et al. In vitro and in vivo enhancement of chemoradiation using the oral parp inhibitor ABT888 in colorectal cancer cells. Int J Radiat Oncol Biol Phys. 2013;86(3):46976. Available from:. https://doi.org/10.1016/j.ijrobp.2013.02.015.

32. Geng L, Huehls AM, Wagner JM, Huntoon CJ, Karnitz LM. Checkpoint signaling, base excision repair, and PARP promote survival of colon cancer cells treated with 5-fluorodeoxyuridine but not 5-fluorouracil. PLoS One. 2011;6(12):e28862. https://doi.org/10.1371/journal.pone.0028862.

33. Mini E, Landini I, Lucarini L, Lapucci A, Napoli C, Perrone G, et al. The inhibitory effects of HYDAMTIQ, a novel PARP inhibitor, on growth in human tumor cell lines with defective DNA damage response pathways. Oncol Res Featur Preclin Clin Cancer Ther. 2017;25(9):1441-51.

34. Haugen AC, Oshimura M, Shibuya K, Zhong X, Yamada K, Koi M, et al. Genetic instability caused by loss of MutS homologue 3 in human colorectal Cancer. Cancer Res. 2008;68(20):8465-72 Available from: http://ca ncerres.aacrjournals.org/cgi/doi/10.1158/0008-5472.CAN-08-0002\%0Apa pers3://publication/doi/10.1158/0008-5472.CAN-08-0002.

35. Berg KCG, Eide PW, Eilertsen IA, Johannessen B, Bruun J, Danielsen SA, et al. Multi-omics of 34 colorectal cancer cell lines - a resource for biomedical studies. Mol Cancer. 2017;16(1):116. https://doi.org/10.1186/s12943-017-0691-y.

36. Chou TC. Drug combination studies and their synergy quantification using the chou-talalay method. Cancer Res. 2010;70(2):440-6. https://doi.org/10.11 58/0008-5472.CAN-09-1947.

37. Chou TC. Theoretical basis, experimental design, and computerized simulation of synergism and antagonism in drug combination studies. Pharmacol Rev. 2006;58(3):621-81. https://doi.org/10.1124/pr.58.3.10.

38. Münz F, Lopez Perez R, Trinh T, Sisombath S, Weber KJ, Wuchter P, et al Human mesenchymal stem cells lose their functional properties after paclitaxel treatment. Sci Rep. 2018;8(1):1-11.

39. Gupta D, Heinen CD. The mismatch repair-dependent DNA damage response: mechanisms and implications. DNA Repair (Amst). 2019;78(March): 60-9. Available from:. https://doi.org/10.1016/j.dnarep.2019.03.009.

40. Longley D, Harkin D, Johnston P. 5-fluorouracil: mechanisms of action and clinical strategies. Nat Rev Cancer. 2003;3(5):330-8. https://doi.org/10.1038/ nrc1074.

41. Gourley C, Balmaña J, Ledermann JA, Serra V, Dent R, Loibl S, et al. Moving from poly (ADP-ribose) polymerase inhibition to targeting DNA repair and DNA damage response in cancer therapy. J Clin Oncol. 2019;37(25):2257-69. https://doi.org/10.1200/JCO.18.02050

42. Francipane MG, Lagasse E. A study of cancer heterogeneity: from genetic instability to epigenetic diversity in colorectal cancer. Cancer Target Drug Deliv An Elus Dream. 2013:363-88. https://doi.org/10.1007/978-1-4614-7876-8_14.

43. Kukolj E, Kaufmann T, Dick AE, Zeillinger R, Gerlich DW, Slade D. PARP inhibition causes premature loss of cohesion in cancer cells. Oncotarget. 2017:8(61):103931-51. https://doi.org/10.18632/oncotarget.21879.

44. Matulonis UA, Monk BJ. PARP inhibitor and chemotherapy combination trials for the treatment of advanced malignancies: does a development pathway forward exist? Ann Oncol. 2017;28(3):443-7. https://doi.org/10.1 093/annonc/mdw697.

45. Wang Y, Qin J. MSH2 and ATR form a signaling module and regulate two branches of the damage response to DNA methylation. Proc Natl Acad Sc U S A. 2003;100(26):15387-92. https://doi.org/10.1073/pnas.2536810100.

46. De Zio D, Cianfanelli V, Cecconi F. New insights into the link between DNA damage and apoptosis. Antioxid Redox Signal. 2013;19(6):559-71. https:// doi.org/10.1089/ars.2012.4938.

47. Fischer $F$, Baerenfaller $\mathrm{K}$, Jiricny J. 5-fluorouracil is efficiently removed from DNA by the base excision and mismatch repair systems. Gastroenterology. 2007;133(6):1858-68. https://doi.org/10.1053/j.gastro.2007.09.003.

48. Meyers M, Wagner MW, Mazurek A, Schmutte C, Fishel R, Boothman DA. DNA mismatch repair-dependent response to fluoropyrimidine-generated damage. J Biol Chem. 2005;280(7):5516-26. https://doi.org/10.1074/jbc.M412105200. 
49. Hassen S, Ali AA, Kilaparty SP, Al-Anbaky QA, Majeed W, Boman BM, et al. Interdependence of DNA mismatch repair proteins $\mathrm{MLH1}$ and $\mathrm{MSH} 2$ in apoptosis in human colorectal carcinoma cell lines. Mol Cell Biochem. 2016; 412(1-2):297-305. https://doi.org/10.1007/s11010-015-2636-3.

50. Carethers JM. Microsatellite instability pathway and EMAST in colorectal cancer. Curr Colorectal Cancer Rep. 2017;13(1):73-80. https://doi.org/10.1 007/s11888-017-0352-y.

51. Park JM, Huang S, Tougeron D, Sinicrope FA. MSH3 mismatch repair protein regulates sensitivity to cytotoxic drugs and a histone deacetylase inhibitor in human colon carcinoma cells. PLoS One. 2013;8(5):e65369. https://doi. org/10.1371/journal.pone.0065369.

52. Murai J, Huang SYN, Das BB, Renaud A, Zhang Y, Doroshow JH, et al. Trapping of PARP1 and PARP2 by clinical PARP inhibitors. Cancer Res. 2012; 72(21):5588-99. https://doi.org/10.1158/0008-5472.CAN-12-2753.

53. Liao H, Ji F, Helleday T, Ying S. Mechanisms for stalled replication fork stabilization: new targets for synthetic lethality strategies in cancer treatments. EMBO Rep. 2018;19(9):1-18.

54. De Angelis PM, Svendsrud DH, Kravik KL, Stokke T. Cellular response to 5fluorouracil (5-FU) in 5-FU-resistant colon cancer cell lines during treatment and recovery. Mol Cancer. 2006:5:1-25.

55. Schoonen PM, Kok YP, Wierenga E, Bakker B, Foijer F, Spierings DCJ, et al. Premature mitotic entry induced by ATR inhibition potentiates olaparib inhibition-mediated genomic instability, inflammatory signaling, and cytotoxicity in BRCA2-deficient cancer cells. Mol Oncol. 2019;13(11):2422-40. https://doi.org/10.1002/1878-0261.12573.

56. Kim H, George E, Ragland R, Rafial S, Zhang R, Krepler C, et al. Targeting the ATR/CHK1 axis with PARP inhibition results in tumor regression in BRCA mutant models. Clin Cancer Res. 2016;23(12):3097-108. https:/doi.org/10.1158/1078-0432.CCR-16-2273.

57. Srinivas US, Dyczkowski J, Beißbarth T, Gaedcke J. 5-Fluorouracil sensitizes colorectal tumor cells towards double stranded DNA breaks by interfering with homologous recombination repair. Oncotarget. 2015;6(14):12574-86. https://doi.org/10.18632/oncotarget.3728.

58. Liu C, Vyas A, Kassab MA, Singh AK, Yu X. The role of poly ADP-ribosylation in the first wave of DNA damage response. Nucleic Acids Res. 2017;45(14): 8129-41. https://doi.org/10.1093/nar/gkx565.

59. Leichman L, Groshen S, ONeil BH, Messersmith W, Berlin J, Chan E, et al. Phase II study of olaparib (AZD-2281) after standard systemic therapies for disseminated colorectal cancer. Oncologist. 2016;21(2):172-7. https://doi. org/10.1634/theoncologist.2015-0319.

60. Kubota E, Williamson CT, Ye R, Elegbede A, Peterson L, Lees-Miller SP, et al. Low ATM protein expression and depletion of p53 correlates with olaparib sensitivity in gastric cancer cell lines. Cell Cycle. 2014;13(13):2129-37. https:/doi.org/10.4161/cc.29212

61. D'Andrea AD. Mechanisms of PARP inhibitor sensitivity and resistance. DNA Repair (Amst). 2018;71(xxxx):172-6. Available from: https:/doi.org/10.1016/j.dnarep.2018.08.021.

62. Maya-Mendoza A, Moudry P, Merchut-Maya JM, Lee M, Strauss R, Bartek J. High speed of fork progression induces DNA replication stress and genomic instability. Nature. 2018;559(7713):279-84. Available from:. https:/doi.org/10.1038/s41586-018-0261-5.

63. Fisher AEO, Hochegger H, Takeda S, Caldecott KW. Poly(ADP-ribose) polymerase 1 accelerates single-Strand break repair in concert with poly(ADP-ribose) glycohydrolase. Mol Cell Biol. 2007;27(15):5597-605. https://doi.org/10.1128/MCB.02248-06.

64. Campregher C, Schmid G, Ferk F, Knasmüller S, Khare V, Kortüm B, et al. MSH3-deficiency initiates EMAST without oncogenic transformation of human colon epithelial cells. PLoS One. 2012;7(11):e50541. https://doi.org/1 0.1371/journal.pone.0050541.

65. Williams SMG, Kuznicki AM, Andrade P, Dolinski BM, Elbi C, Hagan RCO, et al. Treatment with the PARP inhibitor, niraparib, sensitizes colorectal cancer cell lines to irinotecan regardless of MSI / MSS status. Cancer Cell Int. 2015;15(1):14. https://doi.org/10.1186/s12935-015-0162-8.

66. Marshall $\mathrm{CH}$, Sokolova AO, McNatty AL, Cheng HH, Eisenberger MA, Bryce AH, et al. Differential response to olaparib treatment among men with metastatic castrationresistant prostate cancer harboring BRCA1 or BRCA2 versus ATM mutations. Eur Urol. 2019;76(4):452-8. Available from:. https://doi.org/10.1016/j.eururo.2019.02.002.

67. Coward J, Harding A. Size does matter: Why polyploid tumor cells are critical drug targets in the war on cancer. Front Oncol. 2014;4(May):1-16.

68. Passaro C, Volpe M, Botta G, Scamardella E, Perruolo G, Gillespie D, et al. PARP inhibitor olaparib increases the oncolytic activity of d1922-947 in invitro and invivo model of anaplastic thyroid carcinoma. Mol Oncol. 2015; 9(1):78-92. Available from:. https://doi.org/10.1016/j.molonc.2014.07.022.

69. Tentori L, Muzi A, Susanna A, Susanna D, Graziani G. MSH3 expression does not influence the sensitivity of colon cancer HCT116 cell line to oxaliplatin and poly (ADP-ribose) polymerase (PARP) inhibitor as monotherapy or in combination. Cancer Chemother Pharmacol. 2013;72(1):117-25. https://doi. org/10.1007/s00280-013-2175-0.

70. Zhang S, Mercado-Uribe I, Hanash S, Liu J. ITRAQ-based proteomic analysis of polyploid giant cancer cells and budding progeny cells reveals several distinct pathways for ovarian cancer development. PLoS One. 2013;8(11):1-16.

71. Arena S, Corti G, Durinikova E, Montone M, Reilly NM, Russo M, et al. A subset of colorectal cancers with cross-sensitivity to olaparib and oxaliplatin. Clin Cancer Res. 2020;26(6):1372-84.

\section{Publisher's Note}

Springer Nature remains neutral with regard to jurisdictional claims in published maps and institutional affiliations.
Ready to submit your research? Choose BMC and benefit from:

- fast, convenient online submission

- thorough peer review by experienced researchers in your field

- rapid publication on acceptance

- support for research data, including large and complex data types

- gold Open Access which fosters wider collaboration and increased citations

- maximum visibility for your research: over $100 \mathrm{M}$ website views per year

At BMC, research is always in progress.

Learn more biomedcentral.com/submissions 